\title{
Sprawozdanie
}

\section{Konferencja Naukowa nt.: Kodyfikacja ustroju władzy sądowniczej?, Warszawa, 17 czerwca 2011 r.}

Dnia 17 czerwca 2011 r. w gmachu Hotelu InterContinental w Warszawie odbyła się konferencja Kodyfikacja ustroju władzy sądowniczej? organizowana przez Redakcję Kwartalnika Stowarzyszenia Sędziów Polskich „Iustitia” oraz Wydawnictwo C.H. Beck.

Wśród gości konferencji znaleźli się: prof. dr hab. M. Zubik - kierownik Katedry Prawa Konstytucyjnego Wydziału Prawa i Administracji Uniwersytetu Warszawskiego, sędzia Trybunału Konstytucyjnego, prof. dr hab. T. Ereciński - kierownik Katedry Postępowania Cywilnego Wydziału Prawa i Administracji Uniwersytetu Warszawskiego, prezes Sądu Najwyższego, przewodniczący Komisji Kodyfikacyjnej Prawa Cywilnego, prof. dr hab. A. Skoczylas - kierownik Katedry Postępowania Administracyjnego Wydziału Prawa i Administracji Uniwersytetu im. Adama Mickiewicza w Poznaniu, członek Biura Orzecznictwa Naczelnego Sądu Administracyjnego, prof. dr hab. A. Marek - kierownik Katedry Prawa Karnego i Kryminologii Uniwersytetu Mikołaja Kopernika w Toruniu, prof. dr hab. A. Śmieja - Instytut Prawa Cywilnego Wydziału Prawa, Administracji i Ekonomii Uniwersytetu Wrocławskiego, sędzia Sądu Najwyższego A. Górski - przewodniczący Krajowej Rady Sądownictwa oraz P. Esse - dyrektor Naczelny Wydawnictwa C.H. Beck. W konferencji ponadto uczestniczyło szereg przedstawicieli środowiska sędziowskiego, prokuratorzy, przedstawiciele świata akademickiego, organizacji pozarządowych oraz aplikanci adwokaccy.

Na początku konferencji mowę wygłosił P. Esse, witając prelegentów oraz zgromadzonych gości. Moderatorem konferencji był sędzia dr K. Markiewicz - redaktor naczelny Kwartalnika Stowarzyszenia Sędziów Polskich „Iustitia”, który wprowadził wszystkich uczestników do panelu dyskusyjnego.

Temat konferencji został zainspirowany między innymi wydarzeniem, kiedy to większość sędziów w Polsce listem otwartym wyraziło protest przeciwko dalszym pracom nad rządowym projektem zmian do ustawy o ustroju 
sądów powszechnych. Głos taki również wyraziły zgromadzenia ogólne sądów okręgowych jak i sądów apelacyjnych. Zaapelowały one o przystąpienie do opracowania aktu prawnego będącego swoistą kodyfikacją ustroju władzy sądowniczej. Identyczne stanowisko zajęło Stowarzyszenie Sędziów Polskich „Iustitia” oraz Krajowa Rada Sądownictwa.

Dr K. Markiewicz podkreślił, iż już twórcy ustawy z dnia 27 lipca $2001 \mathrm{r}$. Prawo o ustroju sądów powszechnych podczas jej uchwalania przedstawiali ją jako ustawę na miarę XXI w. Jednakże była ona kilkadziesiąt razy nowelizowana, a Trybunał Konstytucyjny kilkakrotnie stwierdzał jej niezgodność z Konstytucją RP. Ponadto stanowiła ona przedmiot krytyki ze strony judykatury, doktryny i osób kierujących obecnie pracami w Ministerstwie Sprawiedliwości. Projektodawcom nowych zmian również zarzuca się brak szerszej wizji prawa ustrojowego. Zamiast jednolitego prawa stanowiącego rozwiązanie i konkretyzację zasad Konstytucji RP i odpowiednich norm międzynarodowych dotyczących władzy sądowniczej nadal funkcjonować będą rozproszone, odrębne regulacje. Stwierdził również, iż „obecna regulacja jest niespójna i uległa wewnętrznemu pęknięciu”. Podkreślił, iż ustawa o Sądzie Najwyższym, prawo o ustroju sądów administracyjnych oraz ustawa o Trybunale Konstytucyjnym bezpośrednio lub pośrednio zawierają ramowe i syntetyczne odesłanie do ustawy Prawo o ustroju sądów powszechnych, przy czym taki zabieg legislacyjny może być źródłem wielu trudności interpretacyjnych, zwłaszcza jeśli zważy się, że w większości przypadków przepisy powyższych ustaw są przepisami niesamodzielnymi. Ponadto uwypuklano, iż każdy z sądów ma odrębną regulację ustrojową, jest reprezentowany przez odrębne organy, inny jest sposób powoływania prezesów, inny jest status sędziów, inne są zasady nadzoru nad sędziami, inne są realia sprawowania wymiaru sprawiedliwości, wreszcie inna jest pozycja poszczególnych sądów i trybunałów w stosunku do władzy wykonawczej i ustawodawczej.

Jako pierwszy z prelegentów wystąpił prof. dr hab. M. Zubik, który podjął temat konstytucyjnych uwarunkowań kodyfikacji przepisów ustrojowych „trzeciej” władzy. W związku z przedstawionym zagadnieniem podjął się nakreślenia problemów, które mogą stanąć na drodze kodyfikacji ustroju władzy sądowniczej. Po pierwsze, postawił problem w warstwie kodyfikacyjnej - usystematyzowania zbioru norm, które mają się pojawić dla konkretnej gałęzi prawa lub dziedziny. Po drugie, wskazał na problem w warstwie le- 
gislacyjnej - kto miałby zasiąść w komisji kodyfikacyjnej, jaki uprawniony organ gotowy już projekt do „laski marszałkowskiej” złoży i będzie go pilotować, aby nie doszło do dekompozycji w trakcie prac parlamentarnych. Po trzecie, zadał pytanie, czy rzeczywiście kodeks jest potrzebny a jeśli tak, to gdzie są punkty niefunkcjonalne, które należałoby zmienić. Jednak najważniejszym zagadnieniem - według prelegenta - jest odpowiedź na pytanie, czy obecnie judykatura stoi przed koniecznością korekty, czy rewizji polskiego ustroju władzy sądowniczej.

Zdaniem prelegenta na pewno co najmniej korekta byłaby konieczna. Jednakże pewne rozwiązania nie będzie dało się poprawić ustawowo bez sięgania do tekstu Konstytucji. Bez zmiany Konstytucji nie będzie możliwe dokonanie takiej korekty ze względu na szeroką regulację sądownictwa w Konstytucji. Jako przykład można podać celowość lub niecelowość istnienia sądów wojskowych. Poza tym mówca wskazał, iż powinno się zastanowić, czy istniejący model gwarancji niezawisłości członków Trybunału Stanu odpowiada konstrukcji, że Trybunał Stanu może orzekać jako sąd karny w stosunku do przestępstw popełnionych przez Prezydenta czy członków Rady Ministrów, ponieważ tylko połowa członków (poza przewodniczącym i wiceprzewodniczącym) musi mieć uprawnienia (nie muszą być sędziami!) do zajmowania stanowiska sędziego. Należy również zastanowić się nad zasadnością dwuinstancyjności w postępowaniu sądowo-administracyjnym czy nie jest za wysokim standardem ochrony prawa do sądu.

Podsumowując, prof. M. Zubik uznał za racjonalny pomysł przeprowadzenia kodyfikacji ustroju władzy sądowniczej, lecz z zastrzeżeniem zachowania wysokiego standardu ochrony prawa do sądu, zapewnienia właściwego statusu sędziowskiego i prawa do uzyskania orzeczenia sądu w rozsądnym terminie. Nadto uznał, iż niezbędna jest komparatystyka, by model ustroju sądownictwa wpisał się w swoisty system podziału władzy.

Prof. dr hab. T. Ereciński w swoim referacie zauważył, iż problemem według niego podstawowym będzie próba usytuowania sądów powszechnych na takim samym poziomie niezależności, jaką ma Sąd Najwyższy. Nie będzie to jednak rzeczą łatwą, ponieważ władza wykonawcza niezbyt chętnie pozbędzie się wpływów na sądy, gdyż tym, co działa na społeczeństwo, jest pryzmat prawa karnego. Prelegent wskazał potrzebę, ażeby w postępowaniu cywilnym w sprawach drobnych orzekano jednoinstancyjnie, ale z za- 
gwarantowaniem dostępu do wymiaru sprawiedliwości i realizacją ochrony praw obywatelskich przez niezależne i niezawisłe sądy.

Sądy powszechne nie powinny być aż tak uzależnione od władzy wykonawczej w gestii finansowej. Zmianą, która budzi poważne wątpliwości, jest projekt menedżerskiego zarządzania sądami, który może doprowadzić do ubezskutecznienia władzy prezesów sądu nad administracją sądową oraz nad sekretariatami. Podmiotem odpowiedzialnym w tym zakresie będzie po ewentualnych zmianach minister sprawiedliwości. Suma uprawnień, które przysługują ministrowi sprawiedliwości, powoduje, że przekroczy to niezależność sądownictwa. Władza wykonawcza, dzięki podobnym regulacjom, przejmuje systematycznie uprawnienia władzy sądowniczej. Jaskrawym zaś naruszeniem jest prawo ministra sprawiedliwości do znoszenia i tworzenia sądów, co narusza prawo do niezawisłego sądu zawarte w art. 6 Konwencji o Ochronie Praw Człowieka.

Zapewnienie finansowej i organizacyjnej sprawności działania, funkcjonowania sądownictwa oraz podejmowania czynności procesowych też leży w gestii i podlega kontroli ministerstwa sprawiedliwości. Bardzo trudno jest rozdzielić pewne czynności administracyjne od czynności związanej z prowadzeniem konkretnej sprawy. Nadzór nie powinien być wykonywany przez ministra sprawiedliwości. Dobrze jest to rozwiązane w sądach administracyjnych, bowiem Naczelny Sąd Administracyjny sprawuje funkcję nadzoru administracyjnego. Jednym $\mathrm{z}$ najtrudniejszych problemów jest jednak to, żeby nadzór administracyjny w szerszym znaczeniu - poza ścisłą administracją, która powinna zostać w rękach rządu - był sprawowany czy to przez Pierwszego Prezesa Sądu Najwyższego, czy to przez Krajową Radę Sądownictwa.

Prof. T. Ereciński uwypuklił również subtelne metody ingerowania polityki w sferę niezależności sądów i niezawisłości sędziów, które odbywa się za sprawą tzw. Czwartej Władzy, która wywołuje wrogą atmosferę, między innymi kreując w mediach wizję łapownictwa w sądach. Zauważył również, iż jeżeli wyroki nie odpowiadają populistycznym oczekiwaniom polityków, to dla nich sądy nie potrafią orzekać zgodnie $\mathrm{z}$ racją stanu.

Prelegent odniósł się również do kwestii samorządu sędziowskiego, który powinien zostać na nowo zdefiniowany. Jak podkreślił, w społeczeństwie obywatelskim idea obrony samorządów jest jedną z najważniejszych dlatego, że jest to podstawowa „transmisja”, dzięki której realizuje się społeczeństwo 
obywatelskie. Samorząd sędziowski jest obecnie rozproszony, gdyż sądy powszechne nie posiadają odpowiedniego organu, jakim dla przykładu jest niewątpliwie Zgromadzenie Ogólne Sędziów Sądu Najwyższego. Zauważył, że sądy, które skupiają największą liczbę sędziów i mają największe obowiązki mają najmniejszą i najgorszą reprezentację, co jest uwidocznione przy wyborach do Krajowej Rady Sądownictwa.

Prof. A. Skoczylas nie negował w zupełności potrzeby zreformowania sądownictwa powszechnego. Zwrócił jednak uwagę, iż ideę wspólnego uregulowania ustroju sądów akcentuje z pewnymi wątpliwościami, przede wszystkim natury konstytucyjnej. Podkreślił, iż sądy administracyjne sprawują kontrolę działalności administracji publicznej, która obejmuje orzekanie o zgodności z ustawami uchwał organów samorządu terytorialnego i aktów normatywnych organów administracji rządowej. Sprawowanie wymiaru sprawiedliwości poprzez kontrolę administracji publicznej należy do sądów administracyjnych, a nie innych sądów. W tym należałoby upatrywać przyjętego w Konstytucji modelu sądownictwa polegającego na wyodrębnieniu dwóch głównych niezależnych od siebie pionów: administracyjnego i powszechnego. Miało to również odzwierciedlenie w dwudziestoleciu międzywojennym oraz u schyłku Polskiej Republiki Ludowej. Prelegent wyraził również zaniepokojenie, iż przy jednolitym systemie sądownictwa w ogromnej części spraw karnych, cywilnych czy rejestrowych sprawy administracyjne stanowiłyby jedynie margines.

Należałoby uwidocznić specyfikę sądownictwa administracyjnego polegającą na tym, iż jest ona i tak naturalnie przeciwstawiona organom administracji publicznej i władzy wykonawczej. Przede wszystkim w kwestii finansowania. Profesor podkreślił, iż w szczególności uwypukla się ona związku z sądową kontrolą organów administracji finansowej. W takiej sytuacji istnieje realna pokusa ze strony administracji rządowej ograniczenia środków finansowych przyznawanych na sądownictwo administracyjne, które niejako przeszkadza w zbieraniu środków budżetowych.

Ponadto wskazał na wątpliwość dotyczące uregulowania w jednym akcie sądownictwa administracyjnego i powszechnego w zakresie wymagań dotyczących sędziów. Zaznaczył, iż w sądownictwie administracyjnym oprócz sędziów wywodzących się z sądów powszechnych są też sędziowie $\mathrm{z}$ rodowodem typowo administracyjnym, którzy przez co najmniej 10 lat pracowali $\mathrm{w}$ organach administracji lub zajmowali się tworzeniem prawa administra- 
cyjnego i nie muszą mieć ukończonej aplikacji ani doświadczenia w sprawach karnych czy cywilnych. Obecność tak przygotowanych sędziów ma ogromne znaczenie dla prawidłowego orzekania przez sądy administracyjne, zwłaszcza w takiej gałęzi prawa administracyjnego, jakim jest prawo podatkowe.

Sesję zakończyła dyskusja związana $\mathrm{z}$ tematyką wygłoszonych referatów, a jej uczestnicy zgodnie podkreślali nadmierną liczbę nowelizacji przepisów prawa, z uwzględnieniem ustawy Prawo o ustroju sądów powszechnych, a także słabość stanowionego prawa. Dało się wyczuć, iż omawiane na konferencji zagadnienie nie pozostanie bez odpowiedzi. Konieczna będzie przemyślana i ujednolicona koncepcja ustroju sądów, statusu sędziego, z likwidacją nadzoru ministra sprawiedliwości oraz niezależnością finansową podobną jak w sądownictwie administracyjnym. Zastanawiano się jedynie, jaki organ podejmie działania zmierzające do skodyfikowania bądź też rewizji polskiego ustroju władzy sądowniczej i czy nowemu „tworowi” nadać rangę kodeksu, czy zwykłej ustawy. Podczas dyskusji poruszono także problem kognicji sądów powszechnych oraz zagadnienie zakresu uprawnień referendarzy.

Paweł Halabowski (Uniwersytet Śląski) 